\title{
SPRAWOZDANIE Z III OGÓLNOPOLSKIEJ KONFERENCJI NAUKOWEJ „PRAWO OCHRONY PRZYRODY A WOLNOŚĆ GOSPODARCZA"
}

W dniach 26-27 września 2011 roku na Uniwersytecie Łódzkim na Wydziale Prawa i Administracji przy ul. Kopcińskiego 8/12 odbyła się trzecia z cyklu konferencji poświęconych prawu ochrony przyrody.

Konferencja stanowiła wspólną inicjatywę Zakładu Prawa Ochrony Środowiska pod kierownictwem prof. zw. dra hab. Marka Górskiego z Wydziału Prawa i Administracji UŁ oraz Katedry Ochrony Przyrody, Wydział Biologii i Ochrony Środowiska UŁ reprezentowanych przez prof. dra hab. Leszek Kucharskiego i prof. dra hab. Romuald Olaczka. Udziału w organizacji przedsięwzięcia podjęło się też Towarzystwo Przyrodników Ziemi Łódzkiej.

Podstawowe założenie konferencji „Prawo ochrony przyrody a wolność gospodarcza", podobnie jak miało to miejsce w latach poprzednich $\mathrm{w}$ ramach tego cyklu, stanowiła z jednej strony

" Doktorant WPiA Uniwersytetu Łódzkiego. 
analiza typowo naukowa, z drugiej zaś wymiana doświadczeń ze świata szeroko pojmowanej praktyki, w przypadku tegorocznego spotkania była to wymiana doświadczeń na temat funkcjonowania prawa ochrony przyrody w realiach wolności gospodarczej. Szczególna uwaga miała być poświęcona analizie przypadków, w których osiągnięto konsensus pomiędzy wolnością gospodarczą a zachowaniem wartości przyrodniczych, co zostało wskazane w poszczególnych referatach, jednak ze względu na analizę takiej a nie innej rzeczywistości prawnej ze wszystkimi jej niedoskonałościami, ilościowo dominowało jednak wskazywanie i omawianie przypadków występowania konfliktów na płaszczyźnie ochrony przyrody w wolności gospodarczej.

Celem spotkania była również prezentacja konkretnych, zarówno skutecznych jak i wadliwych, rozwiązań mających minimalizować negatywny wpływ działalności gospodarczej na środowisko. W szczególności przedmiot zainteresowania stanowiła problematyka gospodarowania zasobami przyrody, szkód środowiskowych oraz ocen oddziaływania na środowisko, w szczególności związanych z inwestycjami gospodarczymi.

Od początku organizatorzy zakładali potrzebę osiągnięcia możliwie dużej interdyscyplinarności konferencji, co oznaczało, że przedmiotem obrad uczyniono wymianę doświadczeń związanych z funkcjonowaniem rozwiązań prawnych z zakresu ochrony przyrody w sposób i w zakresie, które pozwalały na uwzględnianie spojrzenia prawników jak również szeroko rozumianej grupy praktyków ochrony przyrody.

Konferencja rozpoczęła się dnia 26 września o godzinie 11.00, kiedy to uroczystej inauguracji konferencji dokonali: gospodarz Wydziału Prawa i Administracji UŁ - prof. nadzw. dr hab. Agnieszka Liszewska, która podkreśliła znaczenie tego typu przedsięwzięć z punktu widzenia władz wydziału, oraz naukowy opiekun konferencji - prof. zw. dr hab. Marek Górski, który zarówno w latach ubiegłych, jak i w roku 2011 nie tylko nadzorował stronę merytoryczną konferencji, ale też udzielał wielu cennych wskazówek w toku jej organizacji, dzięki czemu w był on w stanie w kilku słowach zarysować zarówno założenia natury doraźnej, organizacyjnej, jak i cele strategiczne konferencji na 3/2011 płaszczyźnie naukowej. 
Obydwu sesjom pierwszego dnia obrad przewodniczył prof. zw. dr hab. Marek Górski, który dodatkowo dokonywał podsumowania poszczególnych etapów obrad zaznaczając najważniejsze elementy poszczególnych wystąpień, dostrzegając ich podobieństwa i różnice oraz wskazując możliwe wnioski wypływajże z tych obserwacji.

Wkrótce po formalnym otwarciu obrad konferencji rozpoczęła się jej pierwsza część. Referat otwierający obrady zaprezentował prof. nadzw. dr hab. Zbigniew Bukowski, który skupił się na relacji w jakiej pozostaje zrównoważony rozwój i gospodarcze korzystanie z zasobów przyrodniczych. W wystąpieniu tym analizie została poddana kwestia uwzględnienia koncepcji zrównoważonego rozwoju w aktach prawnych dotyczących gospodarczego korzystania z zasobów przyrodniczych. Przytaczając liczne argumenty odnoszące się do szerokiego spektrum aktów regulujących gospodarcze korzystanie ze środowiska prof. Zbigniew Bukowski wykazał, iż koncepcja ta jest w nich wykorzystywana w niewystarczającym stopniu.

Nauki ekonomiczne reprezentował kolejny prelegent, pani prof. Małgorzata Burchard - Dziubińska z Wydziału Ekonomiczno -Socjologicznego UŁ, która obszernie zaprezentowała problematykę ekonomicznych skutków ochrony siedlisk w ramach sieci Natura 2000.

Dr Maciej Nyka z Wydziału Prawa i Administracji Uniwersytetu Gdańskiego interesująco przedstawił zagadnienia skupiające się wokół miejsca, jakie ma ochrona przyrody w międzynarodowym prawie gospodarczym. Na podkreślenie zasługuje fakt, że także ten referat wpisywał się doskonale w kontekst problematyki roli i znaczenia zrównoważonego rozwoju jako koncepcji istotnej dla ochrony środowiska, gospodarki oraz interakcji pomiędzy tymi dziedzinami. W tym sensie referat dra Macieja Nyki należy uznać za rozwinięcie o aspekt prawno-międzynarodowy i prawno-gospodarczy zrównoważonego rozwoju, który jako koncepcję prawną omówił i ocenił w pierwszym wystąpieniu prof. Zbigniew Bukowski. W wystąpieniu dra Macieja Nyki niebagatelna rolę odegrało zarysowanie historycznego tła przemian roli międzynarodowego prawa gospodarczego, które wcześniej postrzegano raczej jako narzędzie realizacji zasady wolności go- 
spodarczej, niejednokrotnie używane do przezwyciężania norm prawa krajowego, które jako nakierowane na realizację polityk wewnętrznych $\mathrm{w}$ tym $\mathrm{m}$. in. ochronę środowiska traktowano wówczas jako przeszkodę dla dalszej liberalizacji gospodarki. Prelegent wskazał, że „przełomem w podejściu do problematyki ochrony przyrody, czy szerzej środowiska naturalnego były lata 90., kiedy to presja opinii publicznej, działania United Nations Environmental Programme, a także rosnąca presja na środowisko naturalne doprowadziły do zmiany w działalności najważniejszych organizacji międzynarodowych tworzących system międzynarodowego prawa gospodarczego". Wskazał także, że aktualnie, „w oparciu o realizację zasady zrównoważonego rozwoju, międzynarodowe prawo gospodarcze stało się w pewnym stopniu prawem integracji ekologicznej".

Pierwsza część obrad konferencji została zakończona pierwszym z wystąpień o tematyce bardziej szczegółowej, wygłoszonym przez dr Joannę Miłkowską - Rębowską i poświęcone rozstrzygnięciu kwestii miejsca ochrony zasobów żywych wód w systemie gospodarki morskiej Unii Europejskiej. Referat ten z jednej strony pozwolił uczestnikom zapoznać się z usystematyzowanym przeglądem etapów rozwoju Wspólnej Polityki Rybołówstwa, by w dalszej jego części możliwe było przedstawienie przez autorkę propozycji reformy WPR a także wskazanie tych aspektów, których rozwiązania projekt reformy nie obejmuje. Pomimo docenienia przez autorkę referatu przełomowej roli WPR, wydźwięk referatu nie mógł nastroić optymistycznie - w podsumowaniu wskazano bowiem, że wprowadzone rozwiązania nie wystarczyły do zatrzymania degradacji ekosystemów morskich i nadmiernej eksploatacji ich zasobów. Wśród problemów wciąż stanowiących przyczynę ww. zagrożeń dla środowiska wskazano m. in.: nadmierną zdolność połowową, komplikację legislacji, brak woli politycznej tworzenia obszarów bezpołowowych.

Po pierwszej sesji wywiązała się kilkunastominutowa dyskusja, w toku której uczestnicy formułowali pytania do prelegentów. Odpowiedzi autorów wystąpień uzupełniane były komentarzami pozostałych uczestników. 
Obrady drugiej sesji pierwszego dnia konferencji (26 września) rozpoczęły się o godzinie 15.15 i trwały, z krótką przerwą do godziny 18.30 .

Sesję drugą o godz. 15.15 otwierał niezwykle szczegółowy referat dr Karoliny Karpus z Katedry Prawa Ochrony Środowiska Uniwersytetu Mikołaja Kopernika w Toruniu, poświęcony określeniu wzajemnych relacji pomiędzy instrumentami prawa ochrony przyrody, jakimi są akty planowania a prawem własności i swobodą przedsiębiorczości.

Kolejne wystąpienie autorstwa mgr Martyny Walas, doktorantki z Katedry Prawa Ochrony Środowiska, także z Uniwersytetu Mikołaja Kopernika w Toruniu, dotyczyło bardzo ważnego z punktu widzenia celów naukowych konferencji, tematu ograniczeń wolności działalności gospodarczej w ustawie o ochronie przyrody. Autorka podkreśliła na wstępie, że celem referatu nie jest przedstawienie wszystkich interakcji pomiędzy wolnością gospodarczą a wszelkimi przepisami prawa polskiego chroniącymi przyrodę, na co zresztą nie znalazłoby się miejsce w ramach ograniczonego czasu każdego z wystąpień. Spośród wielu różnych regulacji, zwierających przepisy ochronne względem przyrody, które pozostają relewantne z punktu widzenia działalności gospodarczej autorka wybrała omówienie regulacji zawartych w ustawie o ochronie przyrody. Podkreślono przy tym, że dominująca jest $\mathrm{w}$ tym przypadku zasada zrównoważonego gospodarowania zasobami przyrody mająca ścisły związek z zasadą zrównoważonego rozwoju, co stanowiło kolejne rozwinięcie tematów podejmowanych wcześniej, w toku obrad sesji pierwszej. W dalszej części wystąpienia miało miejsce wskazanie, w jaki sposób i w jakim zakresie, ustawodawca polski stara się realizować powyższe zasady oraz w jaki sposób poszukuje on dróg jednoczesnej i niewykluczającej się realizacji wolnością działalności gospodarczej oraz ochrony przyrody.

Dr Kamila Sobieraj z Wydziału Prawa, Prawa Kanonicznego i Administracji Katolickiego uniwersytetu Lubelskiego Jana Pawła II, w referacie przygotowanym wspólnie z dr Anną Haładyj (także WPPKiA KUL) omówiła szereg wybranych zagadnień środowiskowych uwarunkowań podejmowania inwestycji w zakresie energetyki jądrowej na obszarze Natura 2000. W refera- 
cie została przedstawiona w szczególności specyfika inwestycji w zakresie energetyki jądrowej, przede wszystkim regulacje szczególne wprowadzone ustawą z dnia 29 czerwca 2011 r. o przygotowaniu i realizacji inwestycji w zakresie obiektów energetyki jądrowej oraz inwestycji towarzyszących w zakresie norm procesowych wprowadzających odrębności dotyczące ogólnych zasad przeprowadzania procedury oceny oddziaływania na środowisko. Referat pozwolił zarówno zaprezentować wybrane aspekty procedury oceny oddziaływania na środowisko istotne w przypadku przedsięwzięć w zakresie energetyki jądrowej, jak i zapoznał uczestników konferencji z poglądami autorek w przedmiocie oceny trafności prezentowanych regulacji i wskazaniem propozycji modyfikacji tych ich elementów, które spotkały się $\mathrm{z}$ oceną krytyczną. Wiele miejsca $\mathrm{w}$ wystąpieniu poświęcono kwestii udziału społeczeństwa w procesie oceny oddziaływania na środowisko inwestycji dotyczących energetyki jądrowej.

Kolejny referat został wygłoszony przez dr Agnieszkę Jaworowicz-Rudolf (Zakład Prawa Ochrony Środowiska WPiA UŁ). Tematyka referatu koncentrowała się wokół prawnych aspektów ochrony terenów zieleni przydrożnej w kontekście budownictwa drogowego. Przedmiotem omówienia była więc nie tylko konfrontacja interesu publicznego odnoszącego się do ochrony przyrody z interesem prywatnym podmiotów gospodarujących, ale też, podobnie jak w poprzednim referacie, konieczność równoważenia i koegzystencji dwóch różnych, przy tym nierzadko trudnych do pogodzenia interesów publicznych - w tym przypadku bowiem ochrona przyrody zestawiana jest z koniecznością rozwoju i modernizacji ciągów komunikacyjnych, nieodzowną dla rozwoju nie tylko gospodarczego, ale i cywilizacyjnego w ogóle. Autorka wskazała, że choć przy budowie nowoczesnych ciągów komunikacyjnych oraz modernizacji dotychczasowych aspekty przyrodnicze i krajobrazowe schodzą na plan drugi to jednak $\mathrm{w}$ aspekcie prawnym zieleń przydrożna pozostaje wprawdzie drugorzędnym, ale jednak pożądanym elementem ciągu komunikacyjnego, co jak wskazano, powinno być wystarczającym nakazem do przypisania jej właściwej roli. W referacie podkreślone zostało, że w procesie planowania miejsca usytuowania przedsięwzięcia drogowego należy w możliwie największym stopniu 
zredukować (docelowo wyeliminować) zakres kolizji z formami ochrony przyrody, korzystając przy tym z metod określonych przepisami prawa, co jest szczególnie istotne w przypadku parków narodowych, parków krajobrazowych, rezerwatów, obszarów Natura 2000, obszarów chronionego krajobrazu.

Zgodnie z sygnalizowanymi wcześniej zamierzeniami organizatorów konferencji, wystąpienia teoretyków były uzupełniane obserwacjami praktyków ochrony środowiska, co pozwoliło uczestnikom konferencji na przyjęcie bardziej zróżnicowanego, wielowymiarowego widzenia problemów częstej konfrontacji i koniecznej, choć niełatwej koegzystencji potrzeby ochrony przyrody z istniejącym stopniem wolności gospodarczej. Środowisko praktyków planowania przestrzennego, a zatem dziedziny mającej niebagatelne znaczenie zarówno dla ochrony przyrody, jak i dla prowadzenia działalności gospodarczej, reprezentowały panie Dorota Sowa, Aneta Tomaczak. (Pracownia Planowania Przestrzennego Architekci T. Brzozowska, A. Tomczak Sp.p. w Łodzi), które wygłosiły referat pod tytułem „Formy ochrony przyrody jako wyznacznik kształtowania przestrzeni”. W toku wystąpienia zostało podkreślone, że choć w każdej z form kształtowania planistycznego przestrzeni pojawia się zagadnienie przyrodnicze to jednak sposób pojmowania „władztwa planistycznego" nie zawsze uwzględnia stosowanie instrumentów do ochrony przyrody. Autorki zauważyły, że „presja inwestycyjna”, błędnie pojmowana „własność gruntowa” oraz proinwestycyjna interpretacja prawa stanowią dużą barierę w ochronie wartości stworzonych przez naturę".

Referat ten był ostatnim pierwszego dnia obrad konferencji, nastąpiła po nim dyskusja i podsumowanie dorobku obydwu sesji, dokonane przez prof. zw. dr hab. Marka Górskiego.

27 września 2011 roku o godz. 9.30 rozpoczęły się obrady trzeciej - ostatniej i zarazem jedynej tego dnia sesji konferencji. Obradom konferencji przewodniczył prof. nadzw. dr hab. Zbigniew Bukowski.

Kontynuację i rozwinięcie tematyki, która poprzedniego dnia zamykała ostatnią sesję w pewnym stopniu stanowił referat dr Anny Fogel z Instytutu Gospodarki Przestrzennej i Mieszkal- 
nictwa w Warszawie. Punctum saliens prezentowanej tematyki stanowiły w tym przypadku analiza prawnych aspektów oceny środowiskowych skutków lokalizacji zabudowy, przede wszystkim mieszkaniowej. Dla podkreślenia wagi poruszenia tego tematu warto zaznaczyć, w ślad za autorką, że inwestycje budowlane o charakterze mieszkaniowym stanowiące istotny przejaw działalności inwestycyjnej, oddziałują na środowisko naturalne w pośredni, często trudny dla zidentyfikowania sposób. W referacie stwierdzono m. in., że: „zabudowa mieszkaniowa, o określonej przepisami powierzchni, zaliczona została do przedsięwzięć mogących potencjalnie znacząco oddziaływać na środowisko. Umożliwia to poddanie takich inwestycji ocenie również na etapie przedsięwzięć. Jednak ze względu na swoją specyfikę, przede wszystkim brak wyraźnych elementów technologicznych, stosowanie przepisów dedykowanych przedsięwzięciom jest $\mathrm{w}$ tym przypadku znacznie utrudnione".

Na konferencji reprezentowany był także Urząd Komunikacji Elektronicznej. Dr Dorota Dziedzic - Chojnacka, radca prawny UKE zaprezentowała obszerny referat na temat procedury uzyskania zezwolenia na usunięcie drzew lub krzewów w pozwoleniu na budowę regionalnej sieci szerokopasmowej - na podstawie przepisów ustawy o wspieraniu rozwoju usług i sieci telekomunikacyjnych. Podstawowym przedmiotem referatu była próba opisu procedury uzyskania zezwolenia na usunięcie drzew lub krzewów w pozwoleniu na budowę regionalnej sieci szerokopasmowej. Zarazem autorka uczyniła temat punktem wyjścia do szerszej prezentacji problematyki tzw. „specustaw” i ich roli w kreowaniu regulacji prawnych związanych z ochroną przyrody.

Kolejnym reprezentantem Urzędu Komunikacji Elektronicznej na konferencji był dyrektor tego urzędu, dr Mariusz Czyżak, który przygotował referat poświecony systemowi prawnej ochrony środowiska przed wpływem pola elektromagnetycznego.

Prelegent podkreślił konieczność działań ochronnych w trzech sferach: technicznej, legislacyjnej oraz społecznej. Jak zostało wskazane, poza dostosowaniem się przedsiębiorców do norm ograniczających szkodliwy wpływ pracy urządzeń telekomunikacyjnych na środowisko stworzeniem systemu instrumentów prawnych nakierowanych na eliminację zagrożeń ze strony 
pola magnetycznego i eliminujących szkodliwe urządzenia z obrotu gospodarczego, dla zapewnienia należytej ochrony istotne jest też podniesienie społecznej świadomości w zakresie wpływu wykorzystania danej technologii na występowanie pól elektromagnetycznych.

Sądownictwo reprezentował na konferencji pan Jan Szuma, asystent w Wojewódzkim Sądzie Administracyjnym w Poznaniu. Prelegent poddał wnikliwej analizie uwarunkowania prawne lokalizacji elektrowni wiatrowych w Polsce, w szczególności zaś obowiązujących regulacji prawnych dotyczących wyboru miejsc pod budowę elektrowni wiatrowych i trybu ich lokalizacji ze szczególnym uwzględnieniem oddziaływania tych przedsięwzięć na człowieka i środowisko naturalne.

Magdalena Łysek doktorantka z Zakładu Prawa Ochrony Środowiska WPiA UŁ, poświęciła swe wystąpienie tematyce ocenie ryzyka przyrodniczego przy realizacji inwestycji w odnawialne źródła energii. W referacie tym zaprezentowane zostały: polityka Unii Europejskiej w dziedzinie zmian klimatu i ochrony bioróżnorodności, uwarunkowania prawne inwestycji OZE, formy ochrony przyrody wrażliwe na inwestycje OZE oraz procedura oceny ryzyka przyrodniczego. W referacie autorka ustosunkowała się do oceny potencjalnego wpływu inwestycji na środowisko przyrodnicze jako etapu prawidłowo przeprowadzonego procesu inwestycyjnego branży odnawialnych źródeł energii. Przez pryzmat kilku wybranych przykładów omówiony został także wpływ inwestycji w odnawialne źródła energii na formy ochrony przyrody. W referacie podkreślono stopień ryzyka i wskazano możliwe negatywne następstwa błędnie przeprowadzonej procedury lokalizacyjnej. Autorka postarała się również uwidocznić metody ograniczania podejmowania błędnych decyzji.

Daniel Chojnacki, doktorant w Instytucie Nauk Prawnych Polskiej Akademii Nauk zajął się problematyką ochrony przyrody $\mathrm{w}$ przepisach dotyczących przygotowania i realizacji inwestycji w zakresie obiektów energetyki jądrowej. Przedmiotem referatu autor uczynił omówienie regulacji dotyczących ochrony przyrody zawartych w kolejnej tzw. specustawie, tj. ustawie z dnia 13 maja 2011 roku o przygotowaniu i realizacji inwestycji w zakresie obiektów energetyki jądrowej oraz inwestycji towarzyszą- 
cych, jak również omówienie regulacji zawartych w znowelizowanej ustawie z dnia 29 listopada 2000 roku Prawo atomowe. Kolejny zatem raz w toku obrad konferencji uwagę uczestników skierowano na problem energetyki jądrowej. Prelegent ustosunkował się do dwóch, zawartych w art. 20 ustawy z dnia 13 maja 2011 roku, modyfikacji postępowania w sprawie wydania decyzji o środowiskowych uwarunkowaniach przedsięwzięcia polegającego na budowie obiektu energetyki jądrowej. W sposób krytyczny prelegent ocenił ograniczenia udziału organizacji ekologicznej w tym postępowaniu do organizacji, które zostały wpisane do rejestru co najmniej na 1 rok przed wszczęciem postępowania oraz do ustawowego określenia terminu zakończenia postępowanie w sprawie wydania decyzji o środowiskowych uwarunkowaniach. Polemiczny charakter wystąpienia przyczynił się do intensyfikacji dyskusji.

Referat zamykający sesję trzecią i zarazem ostatni spośród wygłaszanych na tegorocznej konferencji, poświęcony był użytkowi ekologicznemu i jego implikacji w warunkach wolności gospodarczej. Autor referatu - Tomasz Banyś (doktorant, WPiA UŁ), zwrócił na wstępie uwagę, że praktyka stosowania użytku ekologicznego może niekiedy ograniczać szereg praw podmiotowych oraz stanowi przeszkodę dla wolności gospodarczej. Jako przykład takiego ograniczenia (dotyczącego bezpośrednio deweloperów) prelegent podał nagłe ustanowienie na danym obszarze użytku ekologicznego wbrew kierunkowi wyznaczonemu przez akty stanowienia prawa w toku wcześniejszej części procesu inwestycyjnego. W sytuacji, w której ustanowienie użytku ekologicznego następuje na wniosek mieszkańców chcących wyrazić sprzeciw wobec konkretnego posunięcia inwestora, może dojść do zablokowania lub wstrzymania procesu inwestycyjnego pomimo formalnego istnienia ostatecznej decyzji o warunkach. W obliczu poczynionych konstatacji prelegent sformułował pytanie, czy zasadne jest wywoływanie tak daleko idących skutków przez uchwałę ustanawiającą na danym obszarze użytek ekologiczny, co przekłada się na powstanie sytuacji niekorzystnej z punktu widzenia podmiotów gospodarczych w tej inwestycji uczestniczących? Przy zachowaniu generalnej akceptacji znaczenia (nieodzowności) użytku ekologicznego dla ochrony 
przyrody, auto referatu postulował wprowadzenie szeregu racjonalnych i konsekwentnych zmian legislacyjnych w przepisach normujących problematykę użytku ekologicznego, w prawie budowlanym oraz przepisach samorządowych. Celem tych zmian legislacyjnych powinno być zagwarantowanie każdorazowego rzeczywistego wyważenia konkurencyjnych wobec siebie interesów i prawidłowe zastosowanie norm obydwu gałęzi prawa w poszczególnych sprawach zgodnie z zasadą proporcjonalności. Następstwem wygłoszenia tego referatu była długa i wielostronna dyskusja, w toku której autor przytoczył szereg orzeczeń w sprawach odnoszących się do poruszanej problematyki, co nie tylko pozwoliło wyczerpująco odpowiedzieć na wszystkie pytania, ale także stanowiło istotne uzupełnienie przedstawianych treści i podbudowanie zawartych w konkluzji poglądów.

Konferencja została zamknięta obszernym podsumowaniem, którego dokonał opiekun naukowy całego przedsięwzięcia, prof. zw. dr hab. Marek Górski. 